\title{
Using Participatory Scenarios to Stimulate Social Learning for Collaborative Sustainable Development
}

\author{
$\underline{\text { Kris A. Johnson }}^{1}$, Genya Dana $^{2}, \underline{\text { Nicholas R. Jordan }}^{3}, \underline{\text { Kathy J. Draeger }}^{4}$, Anne Kapuscinski $^{5}{ }^{5} \underline{\text { Laura K. Schmitt Olabisi }}^{6}$, and \\ Peter B. Reich ${ }^{7}$
}

ABSTRACT. Interdependent human and biophysical systems are highly complex and behave in unpredictable and uncontrollable ways. Social and ecological challenges that emerge from this complexity often defy straightforward solutions, and efforts to address these problems will require not only scientific and technological capabilities but also learning and adaptation.

Scenarios are a useful tool for grappling with the uncertainty and complexity of social-ecological challenges because they enable participants to build adaptive capacity through the contemplation of multiple future possibilities. Furthermore, scenarios provide a platform for social learning, which is critical to acting in the face of uncertain, complex, and conflict-laden problems. We studied the Minnesota 2050 project, a collaborative project through which citizens collectively imagined future scenarios and contemplated the implications of these possibilities for the adaptability of their social and environmental communities.

Survey and interview data indicate that these participatory scenario workshops built and strengthened relationships, enhanced participants' understanding of other perspectives, and triggered systemic thinking, all of which is relevant to collective efforts to respond to social-ecological challenges through sustainable development activities. Our analysis shows that participatory scenarios can stimulate social learning by enabling participants to engage and to discuss options for coping with uncertainty through collaborative actions. Such learning can be of value to participants and to the organizations and decisions in which they are engaged, and scenario processes can be effective tools for supporting collaborative sustainable development efforts.

Key Words: adaptive capacity; collaborative action; participatory scenarios; social-ecological challenges; social learning; sustainable development

\section{INTRODUCTION}

Many critical environmental and social challenges such as climate change, poverty, ecosystem degradation, and widespread hunger are "wicked" problems (Rittel and Webber 1973) that defy simple solutions. These complex issues emerge from interdependent ecological and human systems and unfold across multiple interacting political, social, and biophysical scales (e.g., Berkes and Folke 1998, Gunderson and Holling 2002). Such challenges that arise from complex social-ecological systems cannot be addressed effectively with narrow "command and control" management (Holling and Meffe 1996), but instead require innovative approaches that incorporate scientific and other forms of knowledge, recognize competing values, and foster communication and negotiation to build collective capacity (Norgaard 1989, Bawden 1991). Engagement of stakeholders and institutions is a critical component of approaches to build adaptive capacity and is essential to conducting effective science for sustainability (e.g., Clark 2007).

Participatory social-ecological research can lead to improved decision-making by developing actions that are more practical and more acceptable to those potentially affected by policies and management (Reed 2008). Involvement of stakeholders in collaborative decision-making also can lead to more equitable governance and support a deliberative democratic approach to governance (Elster 1998), whereby a diversity of values and perspectives are integrated through public deliberation (Yankelovich 1991). Furthermore, application of expert-driven, science-based solutions to sustainability challenges, developed without the involvement of citizens and practitioners, may be untenable in a "shared-power" world (Bryson and Crosby 1992) where actions and decision-making happen at multiple levels of governance and across overlapping public and private institutions. Complex, dynamic, and multiscale social-ecological challenges are illsuited to unilateral regulatory or policy mechanisms; instead, these challenges call for an ongoing process of "socialenvironmental learning” (Finger and Verlaan 1995).

\section{Social learning}

Social learning is an emerging concept that is informed by a variety of fields of scholarship, ranging from social psychology and adult education, to planning and international development (see Muro and Jeffrey 2008 for a review). The idea of social learning emerged from studies of individual

\footnotetext{
${ }^{1}$ Institute on the Environment, University of Minnesota, ${ }^{2}$ Dana \& Sharpe Risk Associates, ${ }^{3}$ Agronomy \& Plant Genetics, University of Minnesota, ${ }^{4}$ Regional Sustainable Development Partnerships, University of Minnesota, ${ }^{5}$ Environmental Studies, Dartmouth College, ${ }^{6}$ Department of Community, Agriculture, Recreation, and Resource Studies, Michigan State University, ${ }^{7}$ Department of Forest Resources, University of Minnesota
} 
learning through the imitation of role models (Bandura 1977) and of experiential learning by adults as they form and reform ideas by testing them against prior experiences (Kolb 1984). Scholars of organizational management expanded discussion of the concept, i.e., beyond analysis of individual cognition, to consider learning within and by interacting groups and organizations (e.g., Argyris and Schon 1978, Senge 1990). The concept of social learning holds promise for sustainable management of complex social-ecological systems (Steyaert and Jiggins 2007) as researchers and managers seek to understand the mechanisms behind effective participatory environmental management processes. Recently, social learning has been studied in community forest management (Wollenberg et al. 2000), water resources (Ison et al. 2007, Steyaert and Jiggins 2007, Pahl-Wostl et al. 2008), the use of natural resources (Rist et al. 2006), wildlife management (Schusler et al. 2003), and environmental risk assessment (Dana and Nelson in press) among other contexts. In particular, social learning is central to the concepts of adaptive management (Holling 1978) and adaptive comanagement (Olsson et al. 2004, Berkes 2009) because learning among groups fosters adaptive capacity to cope with socialecological complexity and to respond to an uncertain future (Tompkins and Adger 2004).

In this paper, we understand social learning to occur when group interactions change individual knowledge and understanding, and this individual learning subsequently influences and informs the group's knowledge and actions (Reed et al. 2010). In particular, social learning emerges among groups of individuals who share differing knowledge and experiences, and it involves the revelation and integration of different and often contrasting participant viewpoints (Mostert et al. 2007). Social learning is both an outcome of, and an essential input to, effective cooperation within a group (Berkes 2009). It arises from a process through which individuals become aware of how others understand reality and reflect upon the alternative ideas and experiences they encounter (Schusler et al. 2003, Keen and Mahanty 2006). Such learning occurs when people interact and share diverse perspectives and experiences, and thus build relationships and develop networks through the process of engaging with others (Schusler et al. 2003). Social learning has the capacity to transform a group of individuals into a community that shares a common interest or goal (Webler et al. 1995), or into a group that can undertake collective action (Wenger 1998, Röling 2002). As such, social learning is an iterative and continuous process that is thought to enhance the flexibility of a socialecological system and increase its ability to respond to change (Pahl-Wostl and Hare 2004).

The growing body of scholarship about the value of social learning has generated important insights for natural resource management and sustainable development, and it has stimulated interest in "new platforms and processes for facilitating social learning" for coping with the complexity of interdependent human and ecological systems (Woodhill and Röling 1998, p. 47). We examined participatory scenarios as one such potential platform, and evaluated the social learning that emerged from a collaborative scenario process in the state of Minnesota.

\section{Scenarios}

Scenarios, as we employ the term, are narratives deliberately crafted to describe multiple plausible futures. They are alternative "possible views of the world" created to help improve understanding and decision-making (Ringland 2002, p. 3). Scenarios allow for expressions of ambiguity through "qualitative causal thinking" (van der Heijden 1996, p. 15) and thus have proven to be well-suited to tackling complex social-ecological problems that are fraught with uncertainty (e.g., Peterson et al. 2003, Bohensky et al. 2006, Carpenter et al. 2005).

Scenarios also offer a vehicle for learning; preparing for an uncertain future shaped by the complex behaviors of socialecological systems requires such learning on an ongoing basis (van der Heijden 1996). Scenarios help integrate varied and diverse ideas by enabling users to coalesce a range of insights into coherent narrative frameworks. They also can be an effective means for individuals to encounter others' viewpoints and expand their own mental models in response (Schwartz 1996, Garb et al. 2008). Scenarios about humanenvironment interactions help participants learn not only about their social-ecological systems, but also about the values and worldviews that shape their own and others' approaches to addressing sustainable development challenges (Bawden 2007). Furthermore, the orientation towards multiple possible futures provides a nonthreatening environment in which to engage other opinions (van der Heijden 1996, Ringland 2002).

Scenarios are often created by "futurists" and "professional builders of scenarios" (Schwartz 1996 p. 10). Yet scenarios need not be the domain of experts alone, rather they can be used to enhance collective action and serve as a platform for collaboration between scientists, citizens, and other stakeholders. Unlike forecasts, which are a "statistical summary of expert opinion" (Berkhout et al. 2002, p. 87), narrative scenarios often do not quantify uncertainty and can be powerful tools for stimulating learning that is independent of technical expertise (Carpenter et al. 2006). Indeed, participation of groups with diverse knowledge, values, and expertise is fundamental to effective scenario development because the strength of scenarios derives from incorporating a breadth of ideas about the future. In recent years, participatory scenarios have been developed in a range of management and decision-making contexts (e.g., Berkhout et al. 2002, Hulse et al. 2004, Kok et al. 2007, Patel et al. 2007, Enfors et al. 2008, Bohensky et al. 2011, Kok et al. 2011). 
Such participatory scenario processes can provide a platform for dialog among citizens, technical experts, and decision makers, and help develop shared capacity to address sustainable development challenges.

We launched a participatory scenario development project in the state of Minnesota in 2007 to evaluate the potential of scenarios to foster participants' capacity to pursue sustainable development in a context of social-ecological uncertainty. We carefully designed participatory scenario processes to stimulate social learning among participants. The key social learning objectives were:

- provide a forum for active, equitable and creative discussion of complex social-ecological systems and inherent future uncertainty;

- build participants' capacity in systemic and strategic thinking related to regional sustainable development projects;

- link different forms of knowledge, including scientific and experiential, and enable participants to share and negotiate different worldviews and perspectives;

- enable participants to create new relationships, and to enhance existing ones, to build their capacities for collective action; and

- inform individual behavior and guide decision-making by individuals and participating organizations and institutions

In this paper we first discuss the unique participatory scenario approach we employed, and then we present results related to the achievement of the above social learning objectives.

\section{METHODS}

\section{Minnesota 2050 project}

The project-Minnesota 2050: Pathways to a Sustainable Future (hereafter referred to as MN 2050)—emerged in 2007 as a collaborative effort between researchers at the University of Minnesota and citizens working with the Regional Sustainable Development Partnerships (RSDPs). The University of Minnesota is a major research university in the United States and it is a public land-grant institution dedicated to substantial engagement of the citizenry of Minnesota. The RSDPs are a citizen-driven network affiliated with the University of Minnesota that works to foster sustainable development around the state. Citizen and faculty boards guide five semi-autonomous regional partnerships and identify community priorities in renewable energy, sustainable agriculture and local foods, natural resource management, and tourism, and leverage the University's resources and expertise to implement local projects. The RSDPs essentially function as a "bridging organization" (Berkes 2009, Folke et al. 2005) between the state and the university that enables citizens to direct university resources and expertise towards regional sustainable development projects.

This academic-public collaboration launched MN 2050 to encourage holistic, long-range thinking and decision-making in Minnesota. We reasoned that a partnership between citizens and scientists that addresses sustainable development in the context of long-term planning could initiate a meaningful dialog and provide useful insights and capacity-building for the RSDPs. MN 2050 was carried out in parallel to, but independent of, a legislatively funded Statewide Conservation and Preservation Plan project. The Statewide Conservation and Preservation Plan collected best-available scientific information about land use, habitat, environmental quality, and natural resource use, and presented recommendations in order to guide policies and funding of conservation activities in Minnesota. Although we linked MN 2050 with this statewide natural resource planning effort through a single scenario workshop in November 2008, we initiated MN 2050 primarily to convene conversations among citizens, university researchers, and community leaders about the complex socialecological systems in Minnesota and beyond.

\section{Workshop design}

Social learning does not simply emerge from every group interaction; rather, it depends on the political, institutional, and social contexts, and on the nature and structure of the participatory process employed (Tippett et al. 2005). With this in mind we designed our scenario workshops to include the participatory process elements that are necessary to stimulate social learning (Fig. 1) (Schusler et al. 2003, Mostert et al. 2007, Muro and Jeffrey 2008). The key process components we chose were: facilitation, democratic structure, and diversity of participants (Daniels and Walker 2001, Mostert et al. 2007). Skilled facilitation is critical to participatory processes because facilitators set the tone for interaction and ensure that the physical and social space is tailored to the needs of the conversation and the participants (Daniels and Walker 2001). A democratically structured process is one which ensures that all participants are able to contribute equally and feel that their input will be heard and respected (Dana and Nelson, in press). Diverse participation promotes inclusion of a greater breadth of worldviews, mental models, and lived experiences in the process (Jones et al. 2011).

A participatory process that incorporates these essential components can generate process attributes that support social learning among participants, including: diversity of knowledge, open and effective communication, unrestrained thinking, constructive conflict, and extended engagement (for example, Daniels and Walker 1996, Schusler et al. 2003, Mostert et al. 2007, Muro and Jeffrey 2008). Diversity of participants enhances the likelihood that the process will incorporate a range of information and varying forms of 
experiential and scientific knowledge (Berkes 2009). Open and effective communication is critical for honest discussions and frank engagement to occur among various knowledge types and those with differing values and opinions (Kahane 2004). Unrestrained thinking fosters creativity, encourages openness to new ideas, and fosters learning across knowledge types (Mostert et al. 2007). Conflict can easily emerge from open communication about contested values and worldviews, yet if managed appropriately, constructive conflict can foster new understanding among diverse participants (Daniels and Walker 2001). Finally, extended engagement enables ongoing and iterative interactions to occur among participants and is also important for fostering social learning (Dana and Nelson, in press).

Fig. 1. Analysis framework for social learning process components, resulting attributes, and potential outcomes. Drawn from Dana and Nelson in press, Mostert et al. 2007, Schusler et al. 2003, and Daniels and Walker 2000.

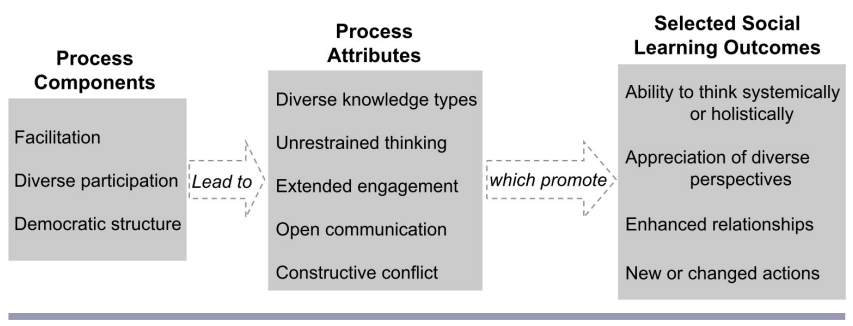

The MN 2050 scenario workshops were designed to incorporate process components and attributes that are important for creating a platform where social learning could occur. The process unfolded in two distinct phases (Phase I and Phase II, Fig. 2), with 10 workshops convened around Minnesota between January, 2007 and June, 2008-two workshops were held in each of the five different RSDP regions of the state. Each workshop involved approximately 30 to 40 local citizens invited by the RSDP regional director. Most participants attended both Phase I and Phase II workshops in their region, but they did not participate in workshops in other regions. Many participants were affiliated with the RSDPs and had participated in other meetings or projects, while others were new to the organization and relatively unfamiliar with sustainable development activities. In all, nearly 200 individuals participated in the workshops. Among the participants were: farmers; small business owners; health care providers; natural resource professionals; county, municipal, and state government leaders; city planners; religious leaders; teachers; high school and college students; and corporate executives.

During Phase I, we convened 1.5-day workshops to develop exploratory scenarios. Participants, working in 4 to 6 small groups of 5 to 6 persons each, used the focal question "How are we interacting with the landscape and natural resources in 2050, and how is the environment affecting our quality of life?" to imagine multiple regional scenarios. The year 2050 was chosen because the researchers and the RSDP leadership wanted to challenge participants to think beyond conventional planning time scales, and in some cases beyond their lifetimes, while still imagining futures that would be very real for their children or grandchildren. We employed the [I]NSPECT process (developed by R. Bawden (personal communication) following from Schwartz 1996), which asks participants to address the focal question by imagining and describing the separate categories of the Natural, Social, Political, Economic, Cultural, and Technological aspects of the possible futures. The "I" in the [I]NSPECT acronym denotes the Interpretation of the individual undertaking the scenario-building exercise, thus explicitly recognizing the importance of individuals' varying worldviews.

In Phase I workshops, small groups completed the [I]NSPECT process, with 20 to 30 minutes allotted for each of the six categories. First, individuals independently envisioned and noted possible future conditions and important drivers of change. Then the small group shared and collected individual insights at the end of working through each category. The [I] NSPECT process generated a series of flip charts, one from each small group, filled with sticky notes containing numerous distinct future possibilities for each category. Following the [I]NSPECT process, the small groups rotated around the room to a different group's set of flip charts. Participants then worked in pairs or small groups to quickly create "scennarratives" by weaving together meaningful future possibilities from the other groups' notes. Then these scennarratives (usually from 1 to 3 per small group, totaling approximately 8 to 15 per region) were shared and discussed among all participants in order to collect additional reflections.

We convened subsequent 1.5-day workshops, 8 to 12 months later during Phase II. Prior to the Phase II workshop in each region, we integrated the scen-narratives generated during Phase I into 4 to 5 more coherent and internally consistent scenarios (Appendix 1). During the Phase II workshops, participants were asked first to individually "inhabit" the scenarios by imagining themselves living in the future time and under the natural, social, political, economic, cultural, or technological conditions described. Participants first acclimated to the potential futures by imagining routine and daily aspects of life, such as how they might travel or prepare meals in the potential future scenarios. Then participants imagined pursuing tasks such as ensuring clean water, securing ample healthy food, or providing sufficient energy. Each small group inhabited two of the 4 to 5 alternative scenarios, and then worked to "backcast", or identify policies or actions that, if taken soon, would make the accomplishment of these important tasks easier. Significantly, the small groups 
Fig. 2. The MN 2050 scenario process. Gray shading highlights the elements of the process that are discussed in this paper. Other papers focus on the interplay between qualitative scenarios and quantitative modeling (Schmitt Olabisi et al. 2010) and on the design and effectiveness of the overall learning system (Kapuscinski et al. unpublished manuscript).

\section{Phase 1 \\ (I)NSPECT}

Phase 2

Statewide Workshop

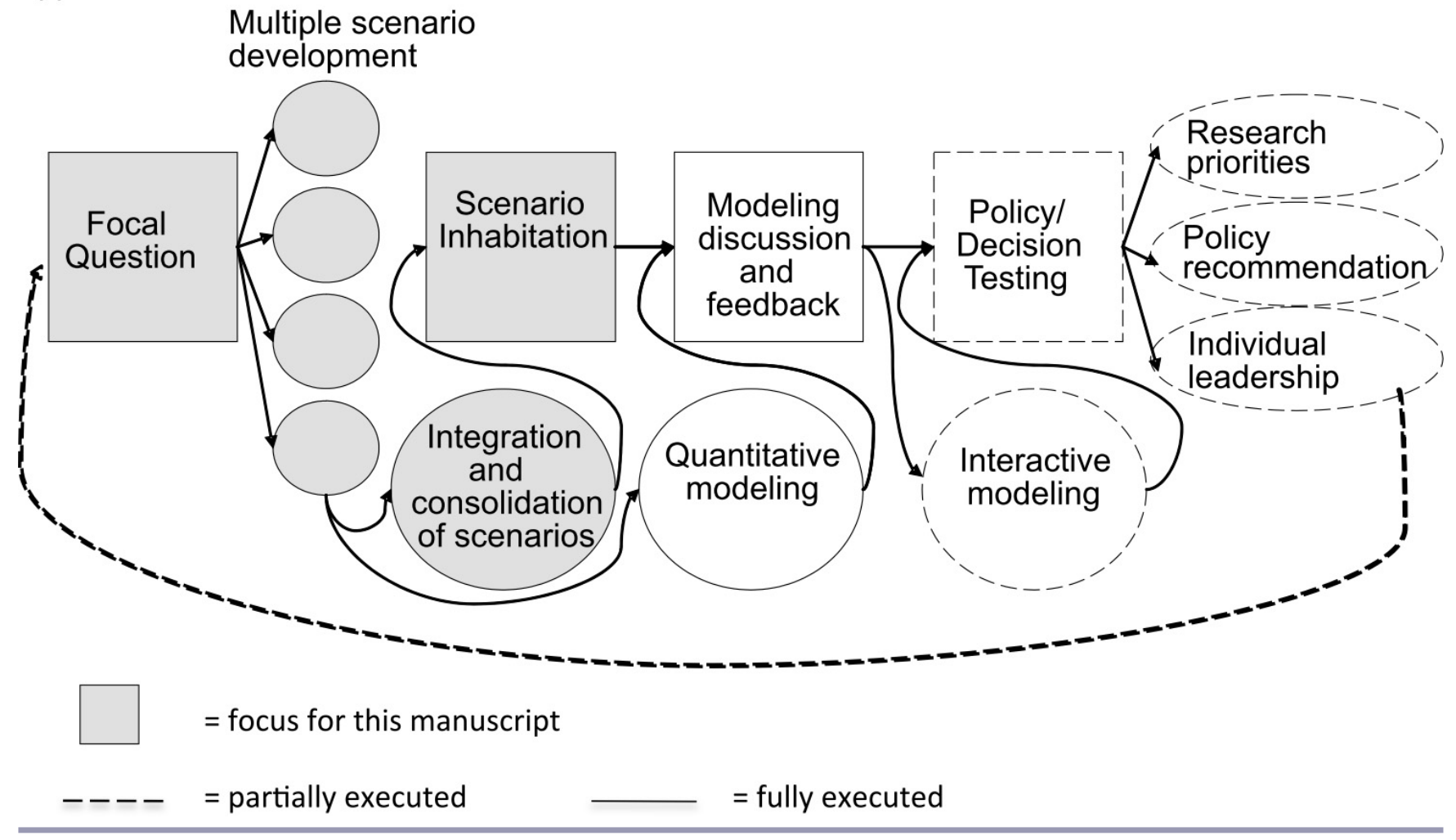

were not asked what could be done in the present to achieve a desirable future or avoid an undesirable one, because in these exercises the core challenge was adapting to, rather than creating the future. Phase II workshops also incorporated a modeled scenario segment in which researchers presented quantitative analysis of critical trends as they might unfold under the alternative scenarios (Schmitt Olabisi et al. 2010).

Two core assumptions of the MN 2050 scenario approach were somewhat distinct from other scenario development processes. First, we characterized the future as being not only uncertain but also to a great extent uncontrollable. We asked participants to reflect on the limited geographic and decisionmaking domains over which they could exercise influence and to understand that national and global social, economic, and biophysical forces would significantly determine future conditions. Rather than seeking to design and create a preferred future, their primary task would be to respond and adapt appropriately. The second distinguishing assumption central to this scenario exercise was the recognition that the process, not the scenarios themselves, was the primary goal.
Participants were fairly unconstrained in the scenario creation process; all scenarios were presumed to be plausible in the exercise, and for the purposes of deriving insights about resilient actions and policies (Appendix 1). Following from this assumption, we do not present the scenarios as results in this paper; rather we discuss in the Results section our analysis of the social learning outcomes. The scenarios appear in Appendix 1.

Both Phase I and Phase II workshops included dedicated time for individual and group reflection, to enable participants to derive meaning from the multiple scenarios that were developed and ponder the divergent values and perspectives surfaced by the group. The workshop elements and the repeated opportunities for engaged discussions within and across groups of participants were specifically designed to foster social learning among participants.

\section{Evaluation of social learning outcomes}

We evaluated social learning outcomes using researcher observation, surveys, and interviews, which are methods 
Table 1. Relationships and appreciation of others' perspectives. Percentage of participants who 'strongly agree' (5 on 1 to 5 scale) and 'mildly agree' ( 4 on 1 to 5 scale) with the following survey statements ( $\mathrm{n}=39$ surveys), and the total number who agree (either 4 or 5 on 1 to 5 scale).

\begin{tabular}{|c|c|c|c|}
\hline This scenario workshop has ... & $\begin{array}{c}\text { Strongly agree } \\
\%(\mathrm{n})\end{array}$ & $\begin{array}{c}\text { Mildly agree } \\
\%(\mathrm{n})\end{array}$ & $\begin{array}{l}\text { Total } \\
\%(\mathrm{n}) \\
\end{array}$ \\
\hline $\begin{array}{l}\text {... strengthened my relationships with other } \\
\text { participants. }\end{array}$ & $79(32)$ & $13(5)$ & $95(37)$ \\
\hline $\begin{array}{l}\text {... improved my understanding of other participants' } \\
\text { perspectives. }\end{array}$ & $62(24)$ & $36(14)$ & $97(38)$ \\
\hline $\begin{array}{l}\text {. . increased my belief that sustainability challenges } \\
\text { can be addressed collectively. }\end{array}$ & $54(21)$ & $38(15)$ & $92(36)$ \\
\hline
\end{tabular}

comparable to those employed in other assessments of social learning (Schusler et al. 2003, Tippet et al. 2005, Mostert et al. 2007). We analyzed data from only the final three workshops because ongoing adaptation of the scenario process in the earlier workshops rendered the process insufficiently uniform to evaluate social learning outcomes at that point. We collected 39 end-of-workshop surveys and completed 14 semistructured phone interviews with select survey respondents about a month after their participation in Phase II workshops. The surveys elicited responses to seven statements about the four social learning outcomes (Tables 1,2, and 3). The interviews included general questions about the scenario workshops and process, and the interviews targeted questions about relationships, workshop interactions, and systems thinking, and actions and outcomes. Multiple researchers observed participant behavior and communication during each of the three workshops, noting evidence of key social learning outcomes as well. Additionally, we conducted follow-up interviews with the five RSDP directors approximately one year after the conclusion of the MN 2050 project to investigate longer-term impacts attributable to the scenario workshops.

We evaluated four commonly studied, and critical, social learning outcomes: ability to think systemically, appreciation of others' perspectives, new or deeper social relations, and anticipated behavioral impacts and outcomes (Muro and Jeffrey 2008). Systems thinking is a crucial component of social learning because individuals are better able to adjust their own mental models when they understand multiple facets of an issue (Daniels and Walker 2001). An appreciation of others' ideas and perspectives is an important outcome because individuals who understand and value different and potentially contrasting worldviews are more likely to learn together and from one another (Mezirow 1996). New and enhanced relationships within the group can indicate that in addition to gaining an understanding of others' perspectives, individuals are also building a foundation on which to deepen collaboration and collective action (Schusler et al. 2003). Finally, changes in individual behavior or the actions of the group thought to arise from a participatory process can provide strong evidence that social learning has occurred (Muro and Jeffrey 2008).

\section{RESULTS AND DISCUSSION}

\section{Process components and attributes}

Drawing on researcher observation of the scenario workshops, we reflected on the extent to which the workshops provided the critical process components and attributes (Fig. 1). The MN 2050 workshops were intentionally designed to provide a democratic structure for the purpose of enabling participants of varying ages, professions, and expertise to engage actively in small and whole-group discussions. Individuals were given equal opportunities to ask questions, provide feedback, and respond to other participants' perspectives. The MN 2050 workshops benefited from excellent facilitation, provided by a professional facilitator with more than 25 years of experience in natural resource planning and environmental management. The facilitator created a comfortable environment and encouraged participants to embrace the improvisation and playfulness of the scenario exercises while acknowledging the seriousness of core values expressed through the process. The democratic structure and excellent facilitation stimulated open communication throughout the workshops. The process was structured to provide repeated opportunities for feedback and questions, and participants were also able to communicate in writing with workshop organizers through packets, evaluations, feedback forms, and group email. No doubt issues of power and status among individuals and between participants and researchers influenced interactions (e.g., Lyon et al. 2010), but the structure and tone of the MN 2050 workshops were designed to be inclusive and open for all participants. Consequently, individuals actively communicated with each other and workshop organizers expressing differing understandings about the topic of sustainability, responding to the opinions of others, and commenting about the scenario process itself. The nature of the MN 2050 scenario process also allowed for unrestrained thinking by prompting individuals to imagine multiple future possibilities for both social and ecological systems, and participants testified to the creative and free thinking encouraged by the workshops. 
Table 2. Systems thinking. Percentage of participants who 'strongly agree' (5 on 1 to 5 scale) and 'mildly agree' (4 on 1 to 5 scale) with the following survey statements ( $n=39$ surveys), and the total number who agree (either 4 or 5 on 1 to 5 scale).

\begin{tabular}{lccc}
\hline \hline This scenario workshop has ... & $\begin{array}{c}\text { Strongly agree } \\
\%(\mathrm{n})\end{array}$ & $\begin{array}{c}\text { Mildly agree } \\
\%(\mathrm{n})\end{array}$ & $\begin{array}{c}\text { Total } \\
\%(\mathrm{n})\end{array}$ \\
\hline $\begin{array}{l}\text {. . increased my understanding of the connections } \\
\text { between the natural, social, political, economic, } \\
\text { cultural, and technological components of } \\
\text { sustainability. }\end{array}$ & $33(13)$ & $49(19)$ & $82(32)$ \\
$\begin{array}{l}\text {. increased my ability to think systemically about } \\
\text { connections between humans and the environment. }\end{array}$ & $33(13)$ & $49(19)$ & $82(32)$ \\
\hline
\end{tabular}

Although some individuals initially found the task of imagining a distant future very challenging, the process quickly stimulated creative brainstorming among participants.

The MN 2050 scenario workshops were less effective at stimulating constructive conflict, perhaps because discussions that were focused on future possibilities were removed from current politically charged issues. For example, conflicting viewpoints about current energy policy were uncovered but conflict was muted because of general agreement that in future scenarios energy would be used more efficiently and would come increasingly from nonfossil fuel sources. The workshops also were less successful at ensuring diverse participation, as nearly all the meetings were convened in rural regions and involved participants who shared some interest in sustainable development and a connection with the RSDPs. Despite this common affiliation, the workshops still included individuals from a variety of professions, with a range of personal interests and experiences, and from various ideological and political perspectives. Nonetheless, more diverse participation, particularly by younger people and underrepresented groups such as new rural immigrants and members of neighboring First Nations, likely would have enhanced the diversity of knowledge types included in the discussions. Finally, the MN 2050 process was also less successful at providing for extended engagement because participants interacted through the MN 2050 workshops for only three days over the course of a year and a half. With significant additional project resources, more extended engagement could have been supported and potentially more opportunities to foster social learning could have been offered.

\section{Social learning outcomes Enhanced relationships}

The majority of survey respondents (32 of 39) agreed strongly that participating in the scenario workshop enhanced existing relationships and helped create new ones as well (Table 1). Although workshop participants were affiliated with the RSDPs, interviewees indicated that they had not known many of the other individuals prior to the workshop but that became acquainted with new people very quickly through the process. One respondent stated that he had known about a quarter of the participants before the scenario workshop and continued his relationships with new acquaintances afterwards. Another interviewee made connections with people that he felt he would not have met otherwise, and believed that the scenario process fostered rapid networking within the group. Several interviewees further stated that the process built or enhanced relationships such that they can contact other workshop participants to exchange ideas or seek collaborative opportunities. Additionally, there was agreement among survey respondents (36 of 39) that the scenario workshop increased their belief that sustainable development challenges are most effectively addressed collectively (Table 1), and as one interviewee stated, nurturing connections among people is "extremely important for sustainability". Four of the five RSDP directors also indicated that the scenario workshops had provided potent networking and relationship-building opportunities that will prove valuable over time. One director referred to a community "green fair" that had organized by newly connected workshop participants in the months following one workshop. Another director, however, indicated that the workshops had minimal relationship-building value because many participants already knew each other, and busy schedules and project overload make it difficult to cultivate new partnering opportunities.

\section{Appreciation for different perspectives}

Nearly two-thirds of survey respondents (24 of 39) strongly agreed that the scenario workshops improved their understanding of others' perspectives; while about one-third indicated mild agreement, and only one respondent thought the workshop had not improved this understanding (Table 1). Many interviewees indicated that they enjoyed and appreciated the "good mix of people" participating, and one person said that the workshop participants were not the people with whom she "normally hangs out". One interviewee stated that because he had not encountered many other participants "like him" at the workshop, he left with a greater understanding 
Table 3. New or changed actions. Percentage of participants who 'strongly agree' (5 on 1 to 5 scale) and 'mildly agree' (4 on 1 to 5 scale) with the following survey statements $(n=39$ surveys), and the total number who agree (either 4 or 5 on 1 to 5 scale).

\begin{tabular}{|c|c|c|c|}
\hline This scenario workshop will ... & $\begin{array}{c}\text { Strongly agree } \\
\%(\mathrm{n})\end{array}$ & $\begin{array}{c}\text { Mildly agree } \\
\%(\mathrm{n})\end{array}$ & $\begin{array}{l}\text { Total } \\
\%(\mathrm{n}) \\
\end{array}$ \\
\hline . . . influence my professional activities. & $31(12)$ & $59(23)$ & $90(35)$ \\
\hline . . . influence my personal lifestyle. & $26(10)$ & $62(24)$ & $87(34)$ \\
\hline
\end{tabular}

of others' values. Another participant admitted that he began reflecting on his notions about the role of economics in supporting sustainable development after being challenged during the scenario process. A third interviewee observed that talking with others allowed him to understand "their vision of reality" and that the scenario process gave contrasting opinions "more legitimacy". Three interviewees also stated that the workshops were much more inclusive of participants' opinions than other meetings about sustainability in which they had participated. They responded that "no one was the boss" during conversations, that all individuals' experiences were highly valued in the process, and that the open nature of discussions led to a "rich tapestry of ideas". Two interviewees also indicated that working in fiction and the future helped them to dissociate from their own ideas and that the scenario process allowed people with disparate views to sit at the same table and talk. Our analysis suggests that participants in the scenario workshops not only became better acquainted with one another, but they also, in a short time, gained a greater understanding of the opinions and perspectives of participants with different worldviews.

\section{Systemic thinking}

The MN 2050 scenario development process was quite systemic in nature because individuals focused on conceiving the wholeness of future possibilities. The [I]NSPECT process emphasized the interdependence of various components of social-ecological systems and obligated participants to reperceive their worlds as manifestations of interacting components of human and environmental systems. The majority of survey respondents (32 out of 39) either agreed or strongly agreed that the scenario workshops had improved their ability to think systemically about connections between humans and the environment (Table 2). Four interviewees stated that the scenario process and its longer time horizons stretched their ability to think systemically. Three interviewees indicated that the workshops and visioning were unlike any other conversations in which they had participated and that they were a great way to break free from "normal thinking". One participant was "jazzed up" by the imaginative systems thinking of the process and said that the scenarios helped him see beyond his own time and place. Another respondent indicated that the process allowed him to "feel" rather than simply think in typical ways, and to flex a "part of his brain not normally used". Several interviewees and survey respondents claimed that they were already thinking systemically prior to the workshops but that the scenario exercise reinforced their perception of interdependence between social and ecological systems. The directors observed that systemic thinking skills carried forward into other discussions after the workshop, with three directors noting that board members seemed more willing to have broad discussions of the RSDPs' long-term mission and goals following participation in the scenario workshops.

\section{New or changed actions}

Another important outcome of social learning is the use of newly acquired individual and collective knowledge to inform and motivate action (e.g., Muro and Jeffrey 2008). To evaluate the scenario workshops' potential influence on subsequent actions, we asked participants whether they thought their participation might influence their personal and professional lives. The majority of survey respondents agreed or strongly agreed that the scenario workshops would influence their professional work (35 of 39) and personal lives (34 of 39). Several interview respondents indicated that the scenario workshops had already influenced them. One related that he had approached meetings with farmers differently following his participation, and that he had introduced the idea of being adaptable to future uncertainty into these usually conventional and conservative conversations. Another stated that he now thinks differently about priorities and regards resilient local food systems to be equally as important for sustainability as renewable energy. Two other interviewees claimed that they had made some modest lifestyle changes such as reducing water use or increasing recycling, but that the impact of the scenario workshops was receding as they returned to their busy day-to-day lives. Three interviewees indicated that they are now reconnected to the RSDPs and more engaged with these groups' sustainable development activities. The directors echoed this, indicating that some individuals became actively engaged or newly connected with the RSDPs following the workshops.

The directors also reported that the scenario exercise helped focus and prioritize the RSDPs' efforts. In particular, four of the five regions became more focused on water issues because 
of the prevalent discussion of water quality and availability across multiple scenario exercises. One region reformulated a committee to focus more on water and others developed plans to fund more water-related research and monitoring or to support education and outreach activities with local partner organizations. Another region began developing a new program to address ecological health that was, according to the director, partly inspired by the scenario workshop discussions. Although the directors all indicated that it was difficult to pinpoint direct impacts from the workshops on the RSDP programs and activities, each of them stated emphatically that the scenario exercise was extremely worthwhile and should be a regular and recurring tool for their organization.

\section{CONCLUSIONS}

The participatory scenario process developed and implemented in the MN 2050 project provided a valuable experience for the individuals involved and stimulated important elements of social learning. Previous social learning evaluations related to environmental decisionmaking or natural resource management have looked for a mix of changes in actions (e.g., new policies, management practices, or pilot projects) and collective capacities (e.g., changes in relationships, knowledge, perspectives, or trust) (Mostert el al. 2007). The social learning outcomes that we observed are similar to those found in studies that investigated changes in the collective capacities of stakeholders after engagement in a participatory process. Scenario workshop participants reported increased knowledge, improved systemic thinking, enhanced relationships, and awareness of new perspectives, all of which are valuable for developing adaptive capacity. These outcomes are similar to those identified in other studies, for example in Measham (2009) where stakeholders worked to manage dry land salinity, and in Schusler et al. (2003) where stakeholders developed Lake Ontario management options, among others. Some social learning evaluations have focused on changes in environmental policies and decision-making, but incorporation of new knowledge and perspectives from other individuals has been identified as a prerequisite for these subsequent higher level institutional changes (Pahl-Wostl et al. 2007). Although we found some evidence of changes in the organizational practices and decision-making of the RSDPs after the scenario workshops, we did not evaluate such potential longer term impacts in detail, but we focused instead on the emergence of critical precursors that support ongoing social learning. However, paper makes a new contribution to social learning scholarship specifically by suggesting that participatory scenarios can support collaborative sustainable development by nourishing changes in a group's fundamental collective capacities.

Limitations in the design and implementation of the MN 2050 process likely diminished the extent to which the workshops stimulated social learning and limited the researchers' opportunities to evaluate the process. We encountered project challenges that are likely to confront other participatory scenario efforts, and we offer some recommendations based upon our analysis and reflections of the MN 2050 project. Attention to these issues may help other researchers maximize social learning among participants and enhance the impacts of future scenario processes.

The first issue is the importance of ensuring the group of participants is diverse. Balanced and appropriate social diversity is a core component of resilience and foundational for enhancing collective action (Nelson et al. 2011). Groups with too little diversity converge quickly and without exchanging contrary ideas, and will necessarily develop fewer options for action. Yet too much diversity can hobble a group and overwhelm a process with too many conflicting values and perspectives. In our experience, the MN 2050 project had too little diversity given the demographics of the regions and the issues of concern; younger participants, immigrants, tribal members, and other rural citizens likely would have brought different perspectives to discussions of local foods, and energy and natural resource use. Our project, and potentially other future participatory scenario efforts, would benefit by ensuring diverse participation that is carefully attuned to the social context and the issues of interest.

The second challenge is the effective promotion and management of constructive conflict. Scenarios allow participants to engage with each other through hypothetical futures and, as a result, may offer a potentially unique vehicle to balance tension among participants (Garb et al. 2008). If channeled properly, conflict can lead to a sharpening of participants' insights and an articulation of mutually acceptable pathways for action (Daniels and Walker 2001). Some scenario development projects have engendered quite a bit of conflict, for example when resulting scenarios were to be used to plot the course of a new government (e.g., Kahane 2004). However, minimal tensions arose in the MN 2050 workshops, likely because participants were discussing distant futures and were not required to choose a particular scenario or identify a preferred policy or decision-making pathway. Future applications of scenario processes could realize potentially greater social learning benefits by stimulating constructive conflict.

A third, and critical, consideration in developing and evaluating processes to promote social learning is the length of engagement among participants (Muro and Jeffrey 2008). In the MN 2050 project each regional community participated in three workshop days over the course of a year and a half, and groups often lacked time to fully discuss important issues and reflect on strategic actions identified through backcasting. We suggest that providing more frequent and ongoing interaction enables participants to get to know and understand 
other individuals' perspectives and to build trust in each other and the participatory process. Allowing time specifically for informal engagement is particularly important, in order for participants to seek out information or expertise from others and to further build relationships (Dana and Nelson, in press). A comprehensive assessment of social learning outcomes would also require longer term engagement and application of additional research methods. Extended social learning research efforts such as the Harmonizing Collaborative Planning (HarmoniCOP) projects (Tippett et al. 2005, Mostert et al. 2007) and Social Learning for Integrated Managing (SLIM) projects (Steyaert and Jiggins 2007) used analysis of completed project documents, information about changes in environmental policies and practices, and the emergence of new organizations as evidence of social learning. Longer engagement with participants also could allow iterative collection of survey or other data, enabling analysis of potential changes in participants' perspectives or identification of emerging consensus (e.g., Stone-Jovicich et al. 2011). However, it could be problematic to attribute social learning outcomes to a particular process rather than to other incidental and independent factors. This challenge notwithstanding, additional longer-term social learning outcomes could be evaluated, including increased trust between participants, the empowerment of communities or enhanced institutional effectiveness and changes in formal environmental decision-making or policies (Daniels and Walker 2001, Pahl-Wostl and Hare 2004, Tippett et al. 2005, Mostert et. al. 2007, Steyaert and Jiggins 2007). Although such outcomes often take significantly more time to emerge than those we assessed during the MN 2050 project (Measham 2009), extended engagement of participants could enhance opportunities, for nurturing social learning as well as for evaluating potential outcomes.

A final and related element that is important to the implementation of scenario processes is the direct and explicit connection between qualitative scenario exercises and concrete decision making. Social learning likely can best support sustainable development when it is embedded in robust institutions and is directly linked to specific decisionmaking (Rist et al. 2006). Although the MN 2050 scenarios generated insights useful to the ongoing work of the RSDPs, the project was directly linked with the formal decisionmaking process of the Statewide Conservation and Preservation Plan through only a single scenario workshop. This workshop was quite effective for the participants who attended but it was just one exercise and occurred fairly late in that natural resource planning process. More iterative connections between the discussion of quantitative scientific information and the qualitative scenario conversations could have stimulated a robust cross-pollination of knowledge types that might have generated useful insights for the Statewide Conservation and Preservation Plan.
However, the incomplete link between the MN 2050 scenarios and direct actions is also partly a function of the fundamental difference between scenario thinking and typical decision processes. Scenarios employ open-ended, creative systems thinking while policy discussions and institutional decisionmaking tends to focus on individual issues or specific nearterm problems. Recent research has begun exploring ways of using visualization tools (e.g., Shaw et al. 2009), mixed qualitative-quantitative methods (e.g., Kok 2009), and other approaches to link insights from scenarios with decisionmaking, but the fundamental differences between scenarios and decision processes make the linking of the two types of processes challenging.

Overall, our analysis adds to the literature by suggesting that scenarios can facilitate social learning about social-ecological systems, and therefore that scenarios constitute a potentially important tool for enhancing collaborative sustainable development efforts. However, to further expand the potential power of this tool, scenario thinking must be more integrally designed into scientific research and traditional decisionmaking processes. Future research that evaluates a variety of scenario processes-employed as part of a strategic participatory approach and explicitly linked to decisionmaking processes-would be useful for enhancing our understanding of the value of scenarios in supporting collaborative sustainable development.

Responses to this article can be read online at: http://www.ecologyandsociety.org/voll7/iss2/art9/responses/

\section{Acknowledgments:}

We thank all of the participants in the Minnesota 2050 scenario workshops for generously sharing their time and energy with this project. We thank Brian Stenquist, not only for his expert facilitation but also his wisdom and guidance throughout the project. We also thank Rachel Brummel for her insights about social learning analysis and for her comments on an earlier draft of this manuscript. Finally, we thank the Archibald Bush Foundation for financial support of KAJ through the Bush Leadership Fellows program, and for funding of the Minnesota 2050 project through the University of Minnesota Ecosystem Science and Sustainability Initiative.

\section{LITERATURE CITED}

Argyris, C., and D. Schön. 1978. Organizational learning: a theory of action perspective. Addison-Wesley, Reading, Berkshire, UK. http://dx.doi.org/10.2307/40183951 
Bandura, A. 1977. Social learning theory. Prentice Hall, Englewood Cliffs, New Jersey, USA. http://dx.doi.org/10.1111/ j.1460-2466.1978.tb01621.x

Bawden, R. J. 1991. Systems thinking and practice in agriculture. Journal of Dairy Science 74:2362-2373. http://d x.doi.org/10.3168/jds.S0022-0302(91)78410-5

Bawden, R. J. 2007. Knowing systems and the environment. Pages 224-234 in J. Pretty, A. Ball, T. Benton, J Guivant, D. Lee, D. Orr, M. Pfeffe,r and H. Ward, editors. Sage handbook on environment and society. Sage Publications, London, UK.

Berkes, F. 2009. Evolution of co-management: role of knowledge generation, bridging organizations and social learning. Journal of Environmental Management 90:1692-1702. http://dx.doi.org/10.1016/j.jenvman.2008.12.001

Berkes, F., and C. Folke, editors. 1998. Linking Social and Ecological Systems: Management Practices and Social Mechanisms for Building Resilience. Cambridge University Press, Cambridge, UK.

Berkhout, F., J. Hertin, and A. Jordan. 2002. Socio-economic futures in climate change impact assessment: using scenarios as 'learning machines'. Global Environmental Change 12:83-95. http://dx.doi.org/10.1016/S0959-3780(02)00006-7

Bohensky, E., J. R. A. Butler, R. Costanza, I. Bohnet, A. Delisle, K. Fabricius, M. Gooch, I. Kubiszewski, G. Lukacs, P. Pert, and E. Wolanski. 2011. Future makers or future takers? A scenario analysis of climate change and the Great Barrier Reef. Global Environmental Change 21: 876-893. http://dx.doi.org/10.1016/j.gloenvcha.2011.03.009

Bohensky, E., B. Reyers, and A. S. van Jaarsveld. 2006. Future ecosystem services in a southern African river basin: a scenario planning approach to uncertainty. Conservation Biology 20:1051-1061. http://dx.doi.org/10.1111/j.1523-173 9.2006.00475.x

Bryson, J., and B. C. Crosby. 1992. Leadership for the common good: tackling public problem in a shared-power world. Jossey-Bass, San Francisco, California, USA.

Carpenter, S. R., E. M. Bennett, and G. D. Peterson. 2006. Scenarios for ecosystem services: an overview. Ecology and Society 11(1):29. [online] URL: http://www.ecologyandsociety. org/vol11/iss1/art29/.

Carpenter, S. R., P. L. Pingali, E. M. Bennett, and M. B. Surek, editors. 2005. Ecosystems and human well-being: scenarios: findings of the scenarios working group. Millennium Ecosystem Series, volume 2. Island Press, Washington, D.C., USA. [online] URL: http://www.maweb.org/en/Scenarios.aspx

Clark, W. C. 2007. Sustainability science: a room of its own. Proceedings of the National Academy of Sciences 104:1737-1738. http://dx.doi.org/10.1073/pnas.0611291104
Dana, G., and K. Nelson. In press. Social learning through environmental risk analysis of biodiversity and GM maize in South Africa. Environmental Policy and Governance.

Daniels, S. E., and G. B. Walker. 1996. Collaborative learning: improving public deliberation in ecosystem-based management. Environmental Impact Assessment 16:71-102. http://dx.doi.or $\mathrm{g} / 10.1016 / 0195-9255(96) 00003-0$

Daniels, S. E., and G. B. Walker. 2001. Working through environmental conflict: the collaborative learning approach. Praeger, Westport, Connecticut, USA.

Elster, J., editor. 1998. Deliberative democracy. Cambridge University Press, Cambridge, UK. http://dx.doi.org/10.1111/j $.1478-9302.2010 .00216 . \mathrm{x}$

Enfors, E. I., L. J. Gordon, G. D. Peterson, and D. Bossio. 2008. Making investments in dryland development: participatory scenario planning in the Makanya Catchment, Tanzania. Ecology and Society 13(2):42. [online] URL: http: //www.ecologyandsociety.org/vol13/iss2/art42/.

Finger, M., and P. Verlaan. 1995. Learning our way out: a conceptual framework for social-environmental learning. World Development 23:503-513. http://dx.doi.org/10.1016/03 05-750X(94)00128-L

Folke, C., T. Hahn, P. Olsson, and J. Norberg. 2005. Adaptive governance of social-ecological systems. Annual Review of Environment and Resources 30:441-473. http://dx.doi.org/10 $.1146 /$ annurev.energy.30.050504.144511

Garb, Y., S. Pulver, and S. Vandeveer. 2008. Scenarios in society, society in scenarios: toward a social scientific analysis of storyline-driven environmental modeling. Environmental Research Letters 3:1-8. http://dx.doi.org/10.1088/1748-9326/ 3/4/045015

Gunderson, L. H., and C. S. Holling, editors. 2002. Panarchy: understanding transformations in human and natural systems. Island Press, Washington, D.C., USA.

Holling, C. S., editor. 1978. Adaptive environmental assessment and management. John Wiley \& Sons, London, UK.

Holling, C. S., and G. K. Meffe. 1996. Command and control and the pathology of natural resource management. Conservation Biology 10:328-337. http://dx.doi.org/10.1046/ j.1523-1739.1996.10020328.x

Hulse, D. W., A. Branscomb, and S. G. Payne. 2004. Envisioning alternatives: using citizen guidance to map future land and water use. Ecological Applications 14:325-341. http ://dx.doi.org/10.1890/02-5260

Ison, R., N. Röling, and D. Watson. 2007. Challenges to science and society in the sustainable management and use of water: investigating the role of social learning. Environmental 
Science and Policy 10:499-511. http://dx.doi.org/10.1016/j.e $\underline{\text { nvsci.2007.02.008 }}$

Jones, N. A., H. Ross, T. Lynam, P. Perez, and A. Leitch. 2011. Mental models: an interdisciplinary synthesis of theory and methods. Ecology and Society 16(1):46. [online] URL: http://www.ecologyandsociety.org/vol16/iss1/art46/.

Kahane, A. 2004. Solving tough problems: an open way of talking, listening, and creating new realities. Berrett-Koehler, San Francisco, California, USA.

Keen, M,. and S. Mahanty. 2006. Learning in sustainable natural resource management: challenges and opportunities in the Pacific. Society and Natural Resources 19:497-513. http://dx.doi.org/10.1080/08941920600663896

Kok, K., R. Biggs, and M. Zurek. 2007. Methods for developing multiscale participatory scenarios: insights from Southern African and Europe. Ecology and Society 13(1):8. [online] URL: http://www.ecologyandsociety.org/vol12/iss1/ $\underline{\operatorname{art} 8 / .}$

Kok, K. 2009. The potential of fuzzy cognitive mapping for semiquantitative scenario development, with an example from Brazil. Global Environmental Change 19:122-133. htt p://dx.doi.org/10.1016/j.gloenvcha.2008.08.003

Kok, K., van Vliet, M., I. Bärlund, A. Dubel, and J. Sendzimir. 2011. Combining participative backcasting and exploratory scenario development: experiences from the SCENES project. Technological Forecasting and Social Change 78:835-851. http://dx.doi.org/10.1016/j.techfore.2011.01.004

Kolb, D. A. 1984. Experiential learning. Prentice Hall, Englewood Cliffs, New Jersey, USA. http://dx.doi.org/10.1016/ B978-0-7506-7223-8.50017-4

Lyon, A., M. Bell, N. S. Croll, R. Jackson, and C. Gratton. 2010. Maculate conceptions: power, process, and creativity in participatory research. Rural Sociology 75:538-559. http:// dx.doi.org/10.1111/j.1549-0831.2010.00030.x

Measham, T. G. 2009. Social learning through evaluation: overcoming constraints for salinity management. Environmental Management 43:1096-1107. http://dx.doi.org/10.1007/s0026 7-008-9265-5

Mezirow, J. 1996. Contemporary paradigms of learning. Adult Education Quarterly 46:158-172. http://dx.doi.org/10.1177/0 $\underline{74171369604600303}$

Mostert, E., C. Pahl-Wostl, Y. Rees, B. Searle, D. Tábara, and J. Tippet. 2007. Social learning in European river basin management: barriers and fostering mechanisms from 10 river basins. Ecology and Society 12(1):19. [online] URL: http://w ww.ecologyandsociety.org/vol12/iss1/art19/.

Muro, M., and P. Jeffrey. 2008. A critical review of the theory and application of social learning in participatory natural resource management processes. Journal of Environmental Planning and Management 51:325-344. http://dx.doi.org/10.1 $\underline{080 / 09640560801977190}$

Nelson, M. C., M. Hegmon, S. R. Kulow, M. A. Peeples, K. W. Kintigh, and A. P. Kinzig. 2011. Resisting diversity: a long-term archaeological study. Ecology and Society 16 (1):25. [online] URL: http://www.ecologyandsociety.org/vol16/ iss $1 / \operatorname{art} 25 /$.

Norgaard, R. B. 1989. The case for methodological pluralism. Ecological Economics 1:37-57. http://dx.doi.org/10.1016/092 $\underline{1-8009(89) 90023-2}$

Olsson, P., C. Folke, and F. Berkes. 2004. Adaptive comanagement for building resilience in social-ecological systems. Environmental Management 34:75-90. http://dx.doi. org/10.1007/s00267-003-0101-7

Pahl-Wostl, C., M. Craps, A. Dewulf, E. Mostert, D. Tabara, and T. Taillieu. 2007. Social learning and water resources management. Ecology and Society 12(2):5. [online] URL: http://www.ecologyandsociety.org/vol12/iss2/art5/.

Pahl-Wostl, C., and M. Hare. 2004. Processes of social learning in integrated resources management. Journal of Community and Applied Social Psychology 14:193-206. http: //dx.doi.org/10.1002/casp.774

Pahl-Wostl, C., E. Mostert, and D. Tabara. 2008. The growing importance of social learning in water resource management and sustainability science. Ecology and Society 13(1):24. [online] URL: http://www.ecologyandsociety.org/vol13/iss1/ art24/.

Patel, M., K. Kok, and D. S. Rothman. 2007. Participatory scenario construction in land use analysis: an insight into the experiences created by stakeholder involvement in the Northern Mediterranean. Land Use Policy 24:546-561. http:// dx.doi.org/10.1016/j.landusepol.2006.02.005

Peterson, G. D., G. S. Cumming, and S. R. Carpenter. 2003. Scenario planning: a tool for conservation in an uncertain world. Conservation Biology 17:358-366. http://dx.doi.org/10 .1046/j.1523-1739.2003.01491.x

Reed, M. S. 2008. Stakeholder participation for environmental management: a literature review. Biological Conservation 141:2417-2431. http://dx.doi.org/10.1016/j.biocon.2008.07.014

Reed, M. S., A. C. Evely, G. Cundill, I. Fazey, J. Glass, A. Laing, J. Newig, B. Parrish, C. Prell, C. Raymond, and L. C. Stringer. 2010. What is social learning? Ecology and Society 15(4): r1. [online] URL: http://www.ecologyandsociety.org/ vol15/iss4/resp1/.

Ringland, G. 2002. Scenarios in public policy. John Wiley \& Sons, Chichester, West Sussex, UK. 
Rist, S., M. Chiddambaranathan, C. Escobar, and U. Wiesmann. 2006. "It was hard to come to mutual understanding..." - the multidimensionality of social learning processes concerned with sustainable natural resource use in India, Africa and Latin America. Systemic Practice Action Research 19:219-237. http://dx.doi.org/10.1007/s11213-0069014-8

Rittel, H. W. J., and M. M. Webber. 1973. Dilemmas in a general theory of planning. Policy Sciences 4:155-169. http:/ /dx.doi.org/10.1007/BF01405730

Röling, N. G. 2002. Beyond the aggregation of individual preferences. Pages 25-48 in C. Leeuwis and R. Pyburn, editors. Wheelbarrows full of frogs: social learning in rural resource management. Koninklijke Van Gorcum, Assen, Drenthe, The Netherlands.

Schmitt Olabisi, L. K., A. R. Kapuscinski, K. A. Johnson, P. B. Reich, B. Stenquist, and K. J. Draeger. 2010. Using scenario visioning and participatory system dynamics modeling to investigate the future: lessons from Minnesota 2050. Sustainability 2:2686-2706. http://dx.doi.org/10.3390/ $\underline{\mathrm{su} 2082686}$

Schusler, T. M., D. J. Decker, and M. J. Pfeffer. 2003. Social learning for collaborative natural resource management. Society and Natural Resources 15:309-326.

Schwartz, P. 1996. The art of the long view: paths to strategic insightfor yourself and your company. Doubleday, New York, New York, USA.

Senge, P. 1990. The fifth discipline. Doubleday, New York, New York, USA. http://dx.doi.org/10.1108/eb025496

Shaw, A., S. Sheppard, S. Burch, D. Flanders, A. Wiek, J. Carmichael, J. Robinson, and S. Cohen. 2009. Making local futures tangible-synthesizing, downscaling, and visualizing climate change scenarios for participatory capacity building. Global Environmental Change 19:447-463. http://dx.doi.org /10.1016/j.gloenvcha.2009.04.002

Steyaert, P., and J. Jiggins. 2007. Governance of complex environmental situations through social learning: a synthesis of SLIM's lessons for research, policy and practice. Environmental Science and Policy 10:575-586.

Stone-Jovicich, S. S., T. Lynam, A. Leitch, and N. A. Jones. 2011. Using consensus analysis to assess mental models about water use and management in the Crocodile River Catchment, South Africa. Ecology and Society 16(1):45. [online] URL: http://www.ecologyandsociety.org/vol16/iss1/art45/.

Tippet, J., B. Searle, C. Pahl-Wostl, and Y. Rees. 2005. Social learning in public participation in river basin management. Environmental Science and Policy 8:287-299. http://dx.doi.o rg/10.1016/j.envsci.2005.03.003
Tompkins, E. L., and W. N. Adger. 2004. Does adaptive management of natural resources enhance resilience to climate change? Ecology and Society 9(2):10. [online] URL: http://w ww.ecologyandsociety.org/vol9/iss2/art10/.

van der Heijden, K. 1996. Scenarios: the art of strategic conversation. Wiley \& Sons, Chichester, West Sussex, UK.

Webler, T., H. Kastenholz, and O. Renn. 1995. Public participation in impact assessment: a social learning perspective. Environmental Impact Assessment Review 1:443-463. http://dx.doi.org/10.1016/0195-9255(95)00043-E

Wenger, E. 1998. Communities of practice: learning, meaning, and identity. Cambridge University Press, Cambridge, UK.

Wollenberg, E., D. Edmunds, and L. Buck. 2000. Using scenarios to make decisions about the future: anticipatory learning for the adaptive co- management of community forests. Landscape and Urban Planning 47:65-77. http://dx.d oi.org/10.1016/S0169-2046(99)00071-7

Woodhill, J., and N. G. Röling. 1998. The second wing of the eagle: the human dimension in learning our way to more sustainable futures. Pages 46-72 in N. G. Röling and M. A. E. Wagemakers, editors. Facilitating sustainable agriculture: participatory learning and adaptive management in times of environmental uncertainty. Cambridge University Press, Cambridge, UK.

Yankelovich, D. 1991. Coming to public judgment: making democracy work in a complex world. Syracuse University Press, Syracuse, New York, USA. 


\section{APPENDIX 1}

The MN 2050 Scenarios

\section{$\underline{\text { RSDP Central Region Scenarios: }}$}

\section{The New Frontier}

Global climate change has caused a range of environmental problems, including loss of biodiversity and changed ecosystems. It severely increased stress on precious water resources. Droughts cause crop failures and famines, and trigger massive refugee crises and population dislocations around the world. Even in our land of lakes, intense cultivation of biomass for energy in the early $21^{\text {st }}$ century and competition for water drew down the water table and caused frequent crop failures.

This global instability and the uncertainty and higher cost of energy have reduced international travel and trade and re-focused attention in $\mathrm{MN}$ on local communities and regional economies. Central MN is more self-reliant and more locally governed, and local planning agencies use innovative watershed-based policies to promote the best use of land. Energy efficient buildings and appropriate technologies are essential because of our need for greater self-sufficiency.

We are not as connected with the rest of the nation and are even only occasionally in touch with friends and relatives more than 50 miles away, but we work to create livable and vital communities. Nearly all of the wild landscapes and native species known to our grandparents are gone; but our highly managed landscape produces nearly all that we need. We have strong families and community-minded neighbors. We have carved out a life on this new frontier.

\section{Feudal Plains}

Central Minnesota is home to the grand estates and private parks of the very few and the very rich. The energy and industrial barons consolidated wealth and power when they staved off the climate and energy crisis with a new generation of nuclear energy. Now tight governmental regulation by the wealthy elites controls land and resources, maintains energy and water stability, and keeps the environmental refugees mostly beyond the borders of the state.

The system also creates a growing divide between the haves and the have-nots; workers till the fields, tend the orchards, and manage the hunting grounds of the wealthy landowners. Non-wealthy citizens are unable to travel and lead a difficult life. There are conflicts and uprisings against the lords, yet "criminals", desperate for a better life, who rise up are dealt with swiftly and severely.

Hardships are eased by time with family and connection with community. The have-nots are drawn together, because they lack the means to have a place of their own. Family and local community thrive among the have-nots, because family and community are essential to their survival. 


\section{Power Collapse - Population decimation}

From a hand written journal found in a deserted house in central continent called North America. Location named Menahga, MN.

12/21/22. Freezing rain throughout the day and continuing into the night. I hate December rains! It should be snow on this date.

12/22/22 Still raining and temperature is dropping. The rain is starting to form ice on the branches and highline wires.

12/23/22 Power is out locally. There are so many lines down they don't know when we will be back on. Have to use the generator but I only have enough gas for two days.

12/24/22 Power is basically out everywhere in the country. The downed lines caused an outage cascade. I can only get one station on the TV by satellite. They are talking about widespread panic.

12/25/22 Merry Christmas! No power, no gas for the generator, can't pump gas in town because no power! Stores are pretty much empty because of looting even out here in the boonies.

12/26/22 Glad I stocked up on ammo for deer hunting. I need to go out and hunt something to live on till things get back to normal. Things are pretty crazy with people stealing and fighting over everything. Didn't realize how dependent we all were on the electric. Think I might as well pack a few things and stay at the hunting shack, easier to heat with the fireplace and has the outhouse.

No further entries.

In 2050 the second generation after the great collapse is just beginning. The people are groups of families that hunt, gather, and garden. Communities are beginning to form, but the distrust arising from the 2022 crises is hard to overcome. Over 90 percent of the population died in the chaos following the electric grid failure.

Ironically, other parts of the world also suffered this power grid collapse either caused by ice or by flooding. In areas of the world where people were less dependent on the electric system they were less immediately affected, but as the world wide economy collapsed, the only survivors were those who were self sustainable.

\section{BioTechia}

On November 9, 2057 I celebrated my $121^{\text {st }}$ birthday. The temp today was 116 degrees.

We drove our new 2057 fuel cell truck to Itasca for a meal that was grown in the new biosphere. The café is run by the new government-controlled food service. The meal consisted of algae on a bed of wild rice, all of which is grown in Petri dishes. We 
watched a movie on rivers that were once in Minnesota. We walked through the state park to see the last Norway pine.

Last night for a birthday gift, my wife gave me a 1"x1" piece of beef reconstituted with water! The water was generated by the community fuel cell that powers our new 30 square block prison. Most of the prisoners are in for food theft and murder.

The government-controlled biospheres now can grow genetically modified corn with an ear measuring 3' in length. Most people refuse to eat it, because it glows and has very little food value. But it is filling.

My son teaches at the state-controlled school. He teaches history. Life is good.

\section{RSDP South East Region Scenarios}

\section{Local Self-Reliance}

- economy driven by locally-owned industries; bartering and trading common

- lower consumption as a result of lower incomes and limited availability and variety of goods

- locally vibrant culture - arts, music, theater produced and performed by local talent and enrich community life; front porches are common

- strong immigrant community comprised of Hmong, Hispanic, African immigrants integrated into communities and share food, culture etc.

- climate change has altered weather and rainfall and impacted local species, but collaborative efforts restore local streams and improve regional ecosystems

- local renewable energy efforts including windmills and biofuels production from prairie grasses, woods and other products

- variety of crops adapted to warmer climate integrated with other food production like aquaculture ponds etc.

- targeted holistic health care limit illness and disease

\section{Climate Change and Social Decline}

- major shifts to climate and SE region has weather and precipitation comparable to southern plains states in $20^{\text {th }}$ century; regular $100^{\circ}$ degree days in summers

- frequent tornadoes and more common flood events

- few large industries and high unemployment

- increased poverty and longer work hours for those lucky enough to have a job as they seek to make ends meet

- $\quad$ species extinctions locally and globally

- expensive health care and reduced access to medical treatment

- community businesses, activity emerging in response to decline 


\section{Climate and Social Collapse}

- corporate-government entities control natural resources and political-military power

- global climate change reduces food and water availability and are intense conflicts waged over access to resources

- ethnic cleansing

- refugees from environmental degradation and resource conflicts flock to SE Minnesota and local population explodes

- localized conflicts over access to resources, housing etc.

- survival skills are essential

- isolation and fear

\section{A Day in the Life of a Techno-Survivor}

- high-tech transit, communication and energy systems

- bullet train and trolleys

- wind turbines and solar panels are everywhere

- technology used to influence local weather, precipitation

- telecommuting; virtual work is common, and links employees with local and more distant colleagues

- climate change and unstable weather, intense and frequent storms prompt people to live in earth mound houses

- wired and virtually interconnected; face time focused on family

\section{$\underline{\text { RSDP West Central Region Scenarios }}$}

\section{Theocratic City-states}

Ongoing war and resource collapse led to small city-states. The Church has stepped into the role of government and our township is governed by a board of tolerant and open clergy. As the wars and resource collapse spread and threatened to engulf all of humanity, we organized our collective around tolerance, understanding, faith and ritual. Everyone's roles are described by tradition, and everything we do has a deeper meaning; each day starts with the welcome ritual and we celebrate life and each other in all that we do. We rose from the chaos of the world, and welcomed immigrants of all backgrounds, whatever their faith and from whatever crisis they sought refuge. Immigrants help farm our township lands and help run our local businesses; we thrive because of our diversity. We use remnants of the old technology when needed, but much of our work has been simplified, localized.

\section{The Promise of Post-Carbon Technology}

Global warming and the depletion of fossil fuels forced a complete renovation in our energy and economy. The U.S. finally adopted a "Cap and Trade" policy in 2012 to curb carbon emissions, and the world has been united in reducing carbon emissions since that 
time. Global warming has been arrested and slightly reversed from the terrible years of 2020-2030.

West-central Minnesota enjoys a robust economy based on renewable energy.

Technological improvements in biomass processing have displaced corn-for-ethanol and replaced it with thermo-chemical conversion of cellulosic biomass. Most vehicles are all electric as battery technology allows a compact sedan to travel about 1000 miles between charges and a full re-charge to be completed in ten minutes (a nice bathroom stop). Wind energy in our region produces all of the upper Midwest anhydrous ammonia needs. Wind powers biogas and solar sources provide all of our electrical needs. The hydrogen fuel cell is still a promising technology.

Row crop production in our area was displaced due to heat and drought, and a perennialbased agriculture now dominates. Local foods play a prominent role and provide a healthier diet; the need for healthcare has been reduced and life expectancy in our region is well over 100 .

There is a diverse and stable workforce in our region. After suffering as refugees, workers and their children remember the tough times and are highly motivated to never let that happen again. They are extremely proud of the role they play to make the world a better place. Life is good.

\title{
The Dark Collapse
}

\author{
Energy Crisis \\ Global Climate Change \\ widespread disease, natural disasters \\ economic collapse, infrastructure breaks down \\ food shortages, water crises, violence \\ stateless nations, tribalization \\ empty cities \\ defensive rural communities \\ fear drives people apart
}

\section{Hallibrother International}

We check in upon waking on our arm implant to let central control know we are ready. We're trained to check-in but they know thru metabolic activity sensors what we are doing. One TV station is on and can't be turned off. No choice in programming propaganda broadcast in support of leaders. Extractive economy means more production, and more natural resource depletion. Profits leave the region; industry controls the land; local environment degraded. Major divisions between haves and have-nots. Government favors industry and wealthy; poor underclass growing.

No expectations of change. No creativity, no imagination, no initiative. Robotic lives. 


\section{Town Meeting}

The small brown horse scampered across the muddy February landscape.

"I'll call this meeting to order," John said, his body rocking in gentle rhythm. A voice in his ear trilled, "John, I'm in the freakn' shower. How am I going to keep notes?"

"Maria, you may be the secretary, but you haven't taken notes once in your life. The "puter does that. You just wanted to mess with us by presenting the image of you in the shower."

"Maybe, maybe not. Is the agenda approved?"

"I'll approve it." The voice was deeper, with a faint accent. "I do want to add an item about visioning."

"Ahmad, you Turkish twit, I don't care what kind of crapola went on around the Caspian, but 'round here visioning is still a hanging offense." An assenting chorus from the other council members filled the air, and they moved on to the financial report.

"We have a current balance of $\$ 17,342$, there is still nearly 26,000 bushels of corn, two casks of brandy, 73 wheels of Cheddar and I think the prosciutto will be ready to eat by Christmas. In addition, the Omaha community owes us server time and those guys out around Clear Lake have promised three loads of hay and a PlayStation XX in exchange for five days of no-wind electricity. Rochester called and they are still willing to pay a surgical procedure up to a transplant or seven appendectomies, in exchange for our spare bearing for the Vesta 1.79 turbine."

"Why are we still getting the kids video games? Couldn't we cancel the PlayStation XX for a turbine bearing repair?"

"Is that a motion, Fred? If not, shut up - I don't want my kids hearing that."

"Well, if the rest of you guys don't want it in a motion, I certainly won't interfere with the will of the whole."

"Plus, your kids would slit your throat and you know it. Next item."

"Public Defense here. Those folks who made it here all the way from Belize are settled down by the lake. They say they know aquaculture, and if we will feed them for six months, they'll be turning out crawfish and have pens built for panfish."

"Is there a motion?"

"I move we provide them with a Level Three diet, with milk supplements for the children, for the period of eight months, at which point if they're not pulling their weight we put them on the road again."

"I'll second that, but keep my wife away from those kids, or she'll never agree to putting them on the road. All those in favor?" 
John didn't think he heard a unanimous vote, but it seemed like more than a hundred, which would be a clear majority so he didn't even ask for a tally vote.

The grass was greening around him, with only a few grimy piles of snow in the shadows of the wind turbines that were the community's main cash crop. Angora goats grazed on the last remnants of the leafy spurge which had almost ruined the pastures until the guy in Dickenson had hooked them up with a goat rancher in the Black Hills with excess inventory.

He dismounted and opened and closed a gate leading into the Season 6 rotational pasture. The mixed prairie grasses were still nearly head high, even after a winter's weather. The ground squished around his boots and he knelt long enough to scoop up a handful of mud, kneading it gently as he stared off to the horizon. Felt good - still a clay loam, but pretty good body and organic matter.

"Any other business to be brought before this board at this time?" He paused a moment and then said, "Hearing none, this meeting of the board of Otrey Township, Big Stone County, State of Minnesota is declared adjourned until next month, date to be determined by when we finish planting wheat."

The little green light in the corner of his peripheral vision, indicating a group conversation, shut off and he was alone with the springtime. He slowly rose to his feet, knees and ankles cracking, after a morning on horseback feeling every day of his 83 years. How much longer? he wondered. I've paid my dues. I was forty when the first crash came, the Middle East blowing up, the no gas, no electricity, no nothing. He remembered being cold and hungry, everyone scared, and yet holding this place together, cutting loose from the grid and getting all the work done during daylight days or when the wind had the turbines cranking out juice, shivering by a woodburner on the cold January days when the wind didn't blow. Catching a deep breath when no one was starving and then the harder work of convincing the neighbors to return to society, hooking back up to the grid, taking in refugees when they could, working to build the connections that could get you through the hard times. Washington not much help, not even before the tsunami and not at all afterwards. The dark years took him away, but then his eye focused on what was nearly beneath his boot. He reached down, plucked, and returned to his feet.

He stretched, and led the horse down the hill to the house and his granddaughter headed up to take the horse to the barn. Eighty years of being a farmer made him not aware that he was aware of everything, from the grape vines along every path to the solar collectors running the water treatment plant.

"Hey sweetheart," his wife said as he came through the door, "How was your day?"

"Pasture looks good, the damn town meeting is over for another month and I saw a blue heron on the slough. Oh, and I found a crocus for you." He held out a small blue flower on a drooping stem. She patted his chest and stuck the flower in a jelly jar above the sink. "Life is good, darling, life is good." 


\section{Statewide Scenarios:}

\section{Regional Self-Reliance}

- skyrocketing energy prices and geo-political instability trigger collapse of international trade

- climate change has altered weather and rainfall, impacted native species and ecosystems and stressed limited water resources

- use of diverse crops adapted to warmer climate is integrated with other food production like aquaculture ponds etc.

- local renewable energy efforts including windmills and biofuels production from prairie grasses, wood and other products

- economy driven by regional and locally-owned industries; bartering, trading, cooperatives common

- reduced consumption as a result of lower incomes and limited availability/variety of consumer goods

- regionally-focused politics and civic engagement through town hall meetings

- diverse immigrant community of Hmong, Hispanic, African immigrants integrated and revitalized rural communities and agricultural economy

- collaborative watershed-based efforts to restore local streams and improve regional ecosystems; open space that creates wildlife corridors highly valued

- communities support health services and target holistic preventive health care, in part because of reduced access to specialists and pharmaceuticals

\section{Pandemic and Socio-economic Collapse}

- Global human populations decimated by new highly virulent disease

- Bubble living: people wear hoods, masks and special gloves

- breakdown of government, infrastructure, energy and food production systems

- immediate and almost total reduction in greenhouse gas emissions, deforestation, resource extraction as global society reverts to pre-industrial scale subsistence

- few large industries and increased poverty, labor shortage leads to opportunities for survivors

- intense conflicts over access to safe resources, housing etc.; high crime, wars, ethnic cleansing

- emergence of nomadic, tribal culture and refugees flock to rural Minnesota for water resources and tillable land

- survival skills are essential

- isolation and fear

\section{Green Industrial Minnesota}

- Energy independence and wind/biomass energy export

- high-tech transit like bullet trains, Individual Rapid Transit Pods, Hydrogen Trolleys 
- huge industrial wind farms in western MN; wave and current power generation in Superior, biomass from agriculture and wood by-products; algae biodiesel; solar panels are everywhere

- water resources tightly controlled and extremely valuable for green industry; technology used to induce precipitation during major droughts

- telecommuting; virtual work is common, and links employees with local and more distant colleagues

- adaptation to unstable weather with high-tech "earth mound" structures resistant to intense and frequent storms and huge temperature swings

- intensive agro-industrial crop management to attain maximal efficient use of water, energy and nutrients

- all available lands in production to meet regional and global energy needs; virtually no parks or other "set-asides" because workable land too valuable

- increased population and in-migration to support green industry

- green buildings and products industry achieves almost carbon-neutral building construction and operation

\section{Urbanized BioTechia}

- population highly concentrated in large cities and urban areas

- regional fossil fuel reserves provide the majority of energy needs

- virtual reality and electronic networks are core component of personal and professional lives

- cutting-edge medical, food, and life-prolonging technology available to wealthy elites

- trade focuses on regional level; most food, raw materials, energy, goods and services come from Midwest US

- cities rely on large urban police and private security forces while rural Minnesotans are more isolated and have to protect themselves and their families

- small middle class and many urban poor

- catastrophic weather events (like tornadoes, droughts and floods) are frequent

\section{Corporate Industrialism}

- corporate-government entities control industry and food production, water and natural resources, and political-military power

- environmental pollutants and greenhouse gas emissions highly regulated under centralized energy production

- powerful energy and industrial barons and high level bureaucrats own land and employ workers in the fields, orchards, and hunting grounds of the wealthy

- uprisings and food riots quickly quelled by state authorities

- media, entertainment and communication systems and education are state-run

- personal activities and resource use monitored and resource degradation significantly reduced through regulation and state oversight

- tight governmental control keeps the environmental refugees mostly beyond the borders of the state 